\title{
Editorial
}

\section{Revista Brasileira de Farmacognosia e o Novo Qualis da Capes}

Julho de 2011 é o prazo em que teremos a finalização do processo de avaliação pelo Institute of Scientific Information (ISI) e, assim, a obtenção do Fator de Impacto da Revista Brasileira de Farmacognosia, já respondendo aos diversos questionamentos que tivemos. Surpreendente é o fato da Revista Brasileira de Farmacognosia, apesar de estar indexada em todas as grandes bases de dados mundiais, ter sido estratificada como B4 pelo Novo Qualis.

Como é de conhecimento amplo, o Qualis da Capes é um dos instrumentos que fundamentam a avaliação dos Programas de Pós-graduação no Brasil e que vem sofrendo diversas críticas por cientistas e, particularmente, editores brasileiros, uma vez que este modelo tirou a possibilidade de que periódicos científicos nacionais tenham metas atingíveis de crescimento. Ainda, dentro de cada área, há uma infinidade de categorias, com grandes diferenças de impacto entre elas, sendo que cada uma tem sua abrangência, capaz de gerar mais ou menos citações. Se, por um lado, o Governo Federal, através do $\mathrm{CNPq}$, tem investido de forma considerável no apoio a periódicos brasileiros, o Novo Qualis parece fazer o papel inverso, pois, preocupados com a avaliação de seus Programas, os pesquisadores brasileiros procurarão publicar seus trabalhos em periódicos melhor estratificados, nos quais dificilmente encontraremos representantes nacionais. Neste mesmo contexto, se os Programas são avaliados pelo quanto e onde publicam, a Revista Brasileira de Farmacognosia poderá ser prejudicada num futuro muito próximo, dentro da própria área da Farmácia. A grande maioria dos Programas de Pós-graduação em Ciências Farmacêuticas tem linhas de pesquisa relacionadas com produtos naturais e, nos últimos anos, foi notável o papel desempenhado pela Revista Brasileira de Farmacognosia no crescimento e fortalecimento desses Programas.

Melhorar nossa posição no Qualis da Capes na área da Farmácia é de fundamental importância para o crescimento da Revista. De nossa parte, precisamos estabelecer metas arrojadas de crescimento e trabalhar arduamente para atingi-las. Para isso, o Conselho Editorial decidiu que, a partir de janeiro de 2010, todos os manuscritos submetidos para publicação deverão estar na língua inglesa. Reafirmando decisões anteriores, trabalhos que relatam atividades antimicrobianas e antioxidantes de extratos sem a devida identificação dos constituintes promotores da ação não serão considerados. Ainda, as normas para publicação serão aprimoradas e a Revista contará com Editores de Seção, que colaborarão na avaliação das submissões nas áreas respectivas. Por outro lado, esperamos que, em breve, o nosso "fator h" no SCImago (http://www.scimagojr.com/), seja, de fato, observado e que nossa estratificação seja reconsiderada pela Capes, a fim de valorizar os periódicos da área que cumprem com sua função de divulgar de parte do que é produzido pela própria pós-graduação da ciência farmacêutica brasileira.

Cid Aimbiré M. Santos

Editor 